\title{
C.М. Юн
}

\section{ПРОЕКТ СОЗДАНИЯ ЗОНЫ СВОБОДНОЙ ТОРГОВЛИ МЕЖДУ ЕВРАЗИЙСКИМ ЭКОНОМИЧЕСКИМ СОЮЗОМ И РЕСПУБЛИКОЙ КОРЕЯ}

Статья выполнена в рамках госзадания Минобрнауки РФ № 30.12939.2018/12.1 «Научно-методическое и нормативно-правовое обеспечение научно-технического, инновационного и образовательного сотрудничества в рамках ЕАЭС».

\begin{abstract}
В статье сравниваются актуальные показатели торгово-экономических связей России и Казахстана с Республикой Корея; рассматриваются экспертные рекомендации 2013 г. в отношении заключения соглашений о зоне свободной торговли товарами между Евразийским экономическим союзом и третьими странами, практика выработки подобных соглашений на протяжении периода с 2015 г. по сентябрь 2018 г.; анализируются процесс становления отношений между ЕАЭС и Республикой Корея, причины «заморозки» переговоров о ЗСТ между ЕАЭС и Республикой Корея.

Ключевые слова: Россия; Казахстан; Евразийский экономический союз; Республика Корея; соглашение о зоне свободной торговли.
\end{abstract}

Республика Корея традиционно входит в тройку ведущих экономических партнеров России в Восточной Азии после Китая и Японии. В последнее время Южная Корея все сильнее оспаривает у Японии второе место в списке российских приоритетов. По итогам 2017 г. Южная Корея впервые обогнала Японию по товарообороту с Россией (19,3 млрд долл. США против 18,3 млрд долл.), несмотря на то, что экономика Южной Кореи в 3 раза меньше, чем экономика Японии. Доля Южной Кореи в российском товарообороте составила в 2017 г. 3,6\% [1]. В 2018 г. тенденция сохранилась: за январь-июль российско-южнокорейский товарооборот составил 12,5 против 11,8 млрд долл. торговли с Японией [2]. В сфере торговли услугами с Россией Сеул давно впереди Токио; например, в 2017 г. оборот составил 1,5 млрд долл. против 0,9 млрд японских показателей [3]. В то же время Япония сохраняет абсолютное лидерство среди азиатских стран по накопленным прямым иностранным инвестициям в России - 15,1 млрд долл. на конец 2016 г. против, например, 8,2 млрд долл. инвестиций из Китая и сравнительно скромных 2,1 млрд долл. южнокорейских инвестиций [4. С. 38].

Новым фактором для российско-южнокорейских отношений стала евразийская интеграция в рамках Евразийского экономического союза (ЕАЭС). ЕАЭС молодое интеграционное объединение, прошедшее путь от Таможенного союза в составе России, Казахстана и Белоруссии с 2010 г. до Евразийского экономического союза в составе уже пяти стран (присоединились Армения и Кыргызстан) с 2015 г. Ядро ЕАЭС - Таможенный союз, который включает свободное перемещение товаров внутри ЕАЭС; единый таможенный тариф и единые меры нетарифного регулирования в отношении третьих стран; единую систему внешнеторгового и таможенного регулирования и единое техническое регулирование. Таким образом, на уровень институтов ЕАЭС перешла значительная часть полномочий по регулированию внешнеэкономических связей России.
Расширение ЕАЭС не стоит в повестке. Зато развивается интеграция со странами Большой Евразии. Первое соглашение о зоне свободной торговли товарами (ЗСТ) было подписано с Вьетнамом в мае 2015 г. и вступило в силу в октябре 2016 г. По соглашению, в частности, Вьетнам сразу отменяет таможенные пошлины более чем на 59\% тарифных линий в общей товарной номенклатуре. В отношении еще $30 \%$ товарной номенклатуры ставки таможенных пошлин будут снижены до $0 \%$ в течение переходного периода, а за рамками договора остаются $12 \%$ товарной номенклатуры [5]. Следует отметить, что проект интеграции ЕАЭС с Вьетнамом - это не только зона свободной торговли товарами, но и дополнительные статьи в сфере инвестиционного взаимодействия и гармонизации регуляторных правил (такие соглашения стали нормой в современной международной практике и получили название «ЗСТ+»). По данным Евразийской экономической комиссии (ЕЭК; постоянно действующий регулирующий орган ЕАЭС), товарооборот между странами ЕАЭС и Вьетнамом вырос на 36\% с 4,3 млрд долл. в 2016 г. до 5,9 млрд дол. в 2017 г. (импорт из Вьетнама в ЕАЭС - на 34,7\%, экспорт во Вьетнам - на 39,5\%). Наибольший рост имел место в торговле между Вьетнамом и Казахстаном (48,2\%, при этом казахстанский экспорт увеличился на 63,7\%), а «торговля Республики Армения и Кыргызской Республики с Вьетнамом начала развиваться с нуля и достигла существенных величин» [6].

Второе соглашение ЕАЭС о ЗСТ, так называемое Временное соглашение, было подписано с Ираном 17 мая 2018 г. Оно охватывает половину объема взаимной торговли и предположительно будет действовать 3 года, в течение которых ЕАЭС и Иран планируют выработать полноформатное соглашение о ЗСТ по почти всей товарной номенклатуре [7]. Также в течение 2015-2016 гг. Высшим Евразийским экономическим советом (ВЕЭС; высший орган ЕАЭС, объединяющий 
глав государств и правительств стран-участниц) были приняты решения о начале переговоров о ЗСТ с Израилем (октябрь 2015 г.), Сербией (май 2016 г.), Египтом, Индией и Сингапуром (декабрь 2016 г.). К сентябрю 2018 г. они находятся на разных стадиях: в случае с Сингапуром, Сербией и Израилем уже идут полноформатные официальные переговоры, тогда как с Египтом и Индией не закончены предварительные, технические консультации [8]. Что касается Китая, то вместо соглашения о ЗСТ, которое видится как очень отдаленная перспектива, в мае 2018 г. между ЕАЭС и КНР было подписано «Соглашение о торгово-экономическом сотрудничестве» как непреференциальное соглашение, нацеленное на снижение нетарифных барьеров.

Отношения между ЕАЭС и Южной Кореей были оформлены двумя Меморандумами о сотрудничестве, подписанными Евразийской экономической комиссией осенью 2015 г. со Службой по государственным закупкам и с Министерством промышленности, торговли и энергетики Республики Корея. Ранее, с декабря 2014 г. началось совместное исследование Всероссийской академии внешней торговли (ВАВТ) и Корейского института международной экономической политики (КИЭП) с целью в том числе «дать конкретные предложения по углублению торгово-экономического и инвестиционного сотрудничества между сторонами» [9]. Фактически подразумевалась экспертная проработка вопроса о целесообразности внедрения зоны свободной торговли между ЕАЭС и Южной Кореей и ее параметрах.

Среди стран ЕАЭС, кроме России, существенные экономические связи с Южной Кореей имеет только Казахстан. Казахстанско-южнокорейский товарооборот в 2015 г. составил 1,4 млрд долл. (2,3\% казахстанского товарооборота), в 2016 г. - 0,7 млрд долл. (1,4\%), в 2017 г. - 1,7 млрд долл. (2,8\%) [10]. Казахстан - основной получатель прямых иностранных инвестиций от Южной Кореи из стран ЕАЭС. На конец 2016 г. они составили около 3 млрд долл. В других странах ЕАЭС значимых инвестиций корейских компаний нет [4. С. 8].

Еще в 2013 г. по заказу ЕЭК российские исследователи из МГИМО(У) и Центра экономических и финансовых исследований и разработок провели комплексное исследование «Определение перспективных партнеров государств - членов Таможенного Союза по заключению соглашений о свободной торговле» [11]. Анализ проводился применительно к Вьетнаму, Израилю, Индии, Индонезии, Монголии, Сингапуру и Республике Корее с точки зрения влияния ЗСТ на динамику ВВП и благосостояние потребителей в Белоруссии, Казахстане и России. В отношении Индонезии и Монголии заключение соглашения о ЗСТ было признано нецелесообразным, в отношении остальных стран целесообразным при определенных условиях. При этом самой позитивной была экспертная оценка целесообразности заключения ЗСТ именно с Южной Кореей («безусловно, имеет смысл») по обоим показателям (выигрыш для Казахстана и России, перекрывающий проигрыш Белоруссии, даже в сценарии устранения всех тарифных барьеров). Кроме того, дополнительным выигрышем для стран ЕАЭС было названо привлечение корейских инвестиций через введение в текст соглашения положений, снижающих барьеры для инвестиций.

Совместное исследование ВАВТ И КИЭП было завершено к началу 2016 г. Расчеты авторов показали, что в сценарии полной либерализации торговли товарами Россия и Республика Корея получают сопоставимые выгоды в терминах изменения ВВП: в краткосрочной перспективе - около $0,05 \%$ роста ВВП в обеих странах, в долгосрочной - 0,12\% роста в России и $0,10 \%$ в Южной Корее. Для остальных стран ЕАЭС изменения ВВП останутся незначительными. В долгосрочной перспективе рост совокупного экспорта России прогнозируется на уровне $1,98 \%$, рост экспорта в Южную Корею - на 57,1\%. Для Южной Кореи показатели роста составят 2,9\% (совокупный экспорт) и 96,8\% (экспорт в страны ЕАЭС) [12. С. 58-69]. С конца 2016 г. начались официальные консультации с участием представителей ЕЭК, стран ЕАЭС и Южной Кореи, предваряющие собственно переговоры о соглашении. Однако до сих пор, на сентябрь 2018 г., не принято решение глав государств и правительств стран ЕАЭС о начале официальных переговоров с Южной Кореей.

По какой же причине Южная Корея, указанная российскими экспертами в 2013 г. как первый приоритет для создания ЗСТ, остается единственной страной из группы государств, с кем прорабатывалась принципиальная возможность введения ЗСТ, но с кем до сих пор не начались переговоры? Официальная позиция ЕАЭС, объясняющая задержку на переговорах, была озвучена, например, министром по торговле ЕЭК Вероникой Никишиной в интервью, опубликованном в газете «Коммерсант» 10 февраля 2017 г.: «По Корее не завершена работа по согласованию, скажем так, рамочных условий начала переговоров. Пока мы провели совместное исследование, и выяснилось, что увеличение экспорта ЕАЭС прогнозируемо, но, скорее всего, будет в два раза меньше, чем у Кореи, от открытия доступа на наш рынок. И для того чтобы сбалансировать эти выгоды, наши столицы, которые видят в Корее серьезного инвестиционного и технологического партнера, хотят, чтобы Корея продемонстрировала готовность как минимум сохранить свою инвестиционную деятельность в отраслях, где она уже присутствует, и ее расширять, - у нас есть определенные запросы на корейские инвестиции» [13]. Остается неизвестным вопрос, в какой степени правительство Южной Кореи готово к сделке с ЕАЭС по формуле «ЗСТ + инвестиции».

С другой стороны, существует неофициальная точка зрения, что переговоры не начинаются из-за того, что российская сторона рассматривает ЗСТ с Южной Кореей как угрозу политике импортозамещения в таких отраслях, как производство автомобилей, бытовой электроники, электротехники. Например, с 
обращением в Минпромторг России против ЗСТ с Южной Кореей публично выступала компания «Полипластик», ведущий российский производитель полимерных труб, поставляющий свою продукцию в том числе на предприятия корейских Hyundai, LGElectronics, Samsung в России [14].

Попытки нового президента Республики Корея Мун Чжэ Ина запустить переговоры о ЗСТ также закончи- лись ничем. На российско-южнокорейском саммите 22 июня 2018 г. Москва и Сеул договорились «прилагать усилия в целях скорейшего начала переговоров о заключении соглашения о свободной торговле услугами и инвестициях между Российской Федерацией и Республикой Корея», а по другим аспектам «условий либерализации торговли» (читай - торговле товарами) - только «продолжить обсуждение» [15].

\section{ЛИТЕРАТУРА}

1. Внешняя торговля с третьими странами // Евразийская экономическая комиссия. 2018. URL: http://www.eurasiancommission.org/ ru/act/integr_i_makroec/dep_stat/tradestat/tables/extra/Documents/2017/12+/E201712_2_6.pdf (дата обращения: 14.06.2018).

2. Внешняя торговля Российской Федерации по основным странам и группам стран за январь-июль 2018 г. // Федеральная таможенная служба. 2018. URL: http://www.customs.ru/attachments/article/25865/WEB UTSA 09.xls (дата обращения: 29.09.2018).

3. Внешняя торговля услугами Российской Федерации по основным странам-партнерам за 2017 год // Центральный банк Российской Федерации. 2018. URL: https://www.cbr.ru/statistics/credit_statistics/trade/64-trade_17.xlsx (дата обращения: 15.06.2018)

4. ЕАЭС и страны Евразийского континента: мониторинг и анализ прямых инвестиций-2017. CПб. : ЦИИ ЕAБР, 2017. URL: https://eabr.org/ upload/iblock/252/EDB-Centre_2017_Report-47_FDI-Eurasia_RUS_1.pdf (дата обращения: 15.06.2018).

5. Вопросы и ответы по Соглашению о свободной торговле между Евразийским экономическим союзом и Социалистической Республикой Вьетнам // Евразийская экономическая комиссия. 2018. C. 13. URL: http://www.eurasiancommission.org/ru/act/trade/dotp/sogl_torg/Documents/Вопросы\%20и\%20ответы\%20по\%20Соглашению\%20о\%20свободной\%20торговле\%20между\%20странами\%20ЕАЭС\%20и\%20Вье тнамом.pdf (дата обращения: 12.06.2018).

6. Либерализация торгового режима между ЕАЭС и Вьетнамом позволила за последний год нарастить товарооборот между сторонами на 36\% // Евразийская экономическая комиссия. 19.06.2018. URL: http://www.eurasiancommission.org/ru/nae/news/Pages/19-06-2018-2.aspx (дата обращения: 27.09.2018).

7. Подписано Временное соглашение, ведущее к образованию зоны свободной торговли между ЕАЭС и Ираном // Евразийская экономическая комиссия. 17.05.2018. URL: http://www.eurasiancommission.org/ru/nae/news/Pages/17-05-2018-1.aspх (дата обращения: 26.09.2018).

8. Проводимые переговоры по заключению соглашений о свободной торговле между ЕАЭС и третьими странами. По состоянию на сентябрь 2018 год // Евразийская экономическая комиссия. URL: http://www.eurasiancommission.org/ru/act/trade/dotp/sogl_torg/Documents/ Пpoводимые\%20переговоры\%20сст_сайт.pdf (дата обращения: 27.09.2018).

9. ЕАЭС и Республика Корея подписали Меморандум о сотрудничестве // Евразийская экономическая комиссия. 30.11.2015. URL: http://www.eurasiancommission.org/ru/nae/news/Pages/30-11-2015-5.aspx (дата обращения: 15.06.2018).

10. Внешняя торговля с третьими странами // Евразийская экономическая комиссия. 2018. URL: http://www.eurasiancommission.org/ru/act/ integr_i_makroec/dep_stat/tradestat/tables/extra/Documents/2017/12+/E201712_2_4.pdf (дата обращения: 29.09.2018).

11. Аннотация к результатам научно-исследовательской работы на тему «Определение перспективных партнеров государств-членов Таможенного Союза по заключению соглашений о свободной торговле» // Евразийская экономическая комиссия. 2018. URL: http://www.eurasiancommission.org/ru/NIR/Lists/List/Attachments/35/18_12_2013_annot.pdf (дата обращения: 15.06.2018).

12. Оценка текущего российско-корейского экономического сотрудничества и перспективы развития на средне- и долгосрочный период / П.А. Кадочников, Е.Б. Рогатных, Е.И. Герман, Т.М. Алиев, А.Ю. Кнобель, А.Н. Соколянская, Ли Чжэ Ён, Квак Сонгил, Ли Чул Вон, Чже Сун Хун, Мин Жиёнг; Всероссийская академия внешней торговли Минэкономразвития России; Корейский институт международной экономической политики. М. : ВАВT, 2016. 153 c. URL: http://www.kiep.go.kr/sub/view.do? bbsId=search_report\&nttId=189412 (дата обращения: 10.10.2018).

13. «За открытие рынков стран-партнеров мы должны заплатить снижением пошлин». Министр торговли ЕЭК Вероника Никишина о планах по расширению свободной торговли // Коммерсант. 10.02.2017. URL: https://www.kommersant.ru/doc/3214431 (дата обращения: 15.06.2018).

14. НПП "Полипластик" просит Минторг ограничить свободную торговлю с Южной Kopeeй // http://www.mrcplast.ru/news-news_open327675.html (дата обращения: 29.09.2018).

15. Совместное заявление Российской Федерации и Республики Корея. 22 июня 2018 года // Официальный сайт Администрации Президента России. URL: http://kremlin.ru/supplement/5321 (дата обращения: 29.09.2018).

\section{Yun Sergey M., Tomsk State University (Tomsk, Russia). E-mail: sergey.yun@ mail.tsu.ru THE EURASIAN ECONOMIC UNION - SOUTH KOREA FREE TRADE AREA PROJECT}

Keywords: Russia; Kazakhstan; the Eurasian Economic Union; South Korea; free trade agreement.

The aim of the research is to explore the reason for the postponement of the Eurasian Economic Union - South Korea negotiations on a free trade area. For this aim the paper first compares the current indicators of Russia and Kazakhstan's trade and economic ties with South Korea. Then it analyzes the 2013 expert recommendations for the conclusion of free trade agreements (FTA) between the Eurasian Economic Union (EAEU) and other countries, as well as the EAEU's experience of negotiating FTAs during the period from 2015 to September 2018. It finally focuses on the relations between the EAEU and the Republic of Korea in the context of the FTA negotiations. To write the paper the author used official materials of Russian government agencies and EAEU institutions.

The research reached the following conclusions. South Korea ranks as Russia's top economic partner in East Asia in terms of trade and investment. The Eurasian integration within the Eurasian Economic Union has become a new factor for Russia - South Korea relations. The core of the EAEU is the Customs Union which transferred a significant part of the competences to regulate Russia's foreign economic relations to the level of the EAEU institutions. As for the rest of the EAEU member states, only Kazakhstan has significant economic ties with South Korea.

The EAEU enlargement is not on the agenda. But integration with the countries of the Greater Eurasia is developing. The first agreement on a free trade zone (FTA) was signed with Vietnam in May 2015 and entered into force in October 2016. The second FTA agreement was signed with Iran on May 17, 2018. Formal or preliminary negotiations on the conclusion of a FTA are being conducted by the Eurasian Economic Union with India, Serbia, Israel, Singapore, Egypt.

Official consultations between South Korea, on the one side, and the Eurasian Economic Commission and EAEU member states, on the other, began in late 2016. Consultations usually precede the formal negotiations on a FTA agreement. Earlier in 2013 Russian experts prepared a comprehensive study of the prospects for concluding free trade agreements with various countries in Asia. It is noteworthy 
that the most positive was the expert assessment of the feasibility of a FTA with South Korea which could both promote EAEU exports and attract Korean investments.

However, the decision of the heads of state and government of EAEU member states to start formal talks with South Korea on the FTA has been postponed. The official reason for the delay is the desire to get from South Korea certain commitments to invest in EAEU states, taking into account the fact that, according to Russian experts, the increase in EAEU exports will be two times less than that of Korea within the FTA. The unofficial explanation is Russia's negative position on the point. The Russian government views the FTA with South Korea as a threat to some Russian industries, including car manufacturing.

\section{REFERENCES}

1. Eurasian Economic Commission. (2018a) Vneshnyaya torgovlya s tret'imi stranami [Foreign Trade with Third Countries]. [Online] Available from: http://www.eurasiancommission.org/ru/act/integr_i_makroec/dep_stat/tradestat/tables/extra/Documents/2017/12+/E201712_2_6.pdf. (Accessed: 14th June 2018).

2. Federal Customs Service. (2018) Vneshnyaya torgovlya Rossiyskoy Federatsii po osnovnym stranam i gruppam stran za yanvar'-iyul' 2018 g. [Foreign trade of the Russian Federation by main countries and groups of countries in January - July 2018]. [Online] Available from: http://www.customs.ru/attachments/article/25865/WEB_UTSA_09.xls. (Accessed: 29th September 2018).

3. Central Bank of the Russian Federation. (2018) Vneshnyaya torgovlya uslugami Rossiyskoy Federatsii po osnovnym stranam-partneram za 2017 god [Foreign trade in services of the Russian Federation by major partner countries for 2017]. [Online] Available from: https://www.cbr.ru/statistics/credit_statistics/trade/64-trade_17.xlsx. (Accessed: 15th June 2018).

4. Eurasian Bank of Development. (2017) EAES $i$ strany Evraziyskogo kontinenta: monitoring i analiz pryamykh investitsiy - 2017 [EAEU and countries of the Eurasian continent: monitoring and analysis of direct investments - 2017]. St. Petersburg: TSII EABR. [Online] Available from: https://eabr.org/upload/iblock/252/EDB-Centre_2017_Report-47_FDI-Eurasia_RUS_1.pdf. (Accessed: 15th June 2018).

5. Eurasian Economic Commission. (2018b) Voprosy i otvety po Soglasheniyu o svobodnoy torgovle mezhdu Evraziyskim ekonomicheskim soyuzom $i$ Sotsialisticheskoy Respublikoy V'etnam [Questions and answers on the Free Trade Agreement between the Eurasian Economic Union and the Socialist Republic of Vietnam]. pp. 13. [Online] Available from: http://www.eurasiancommission.org/ru/act/trade/dotp/sogl_torg/Documents/Voprosy $\% 20 \mathrm{i} \% 20$ otvety $\% 20$ po\%20Soglasheniyu $\% 20 \mathrm{o} \% 20$ svobodnoy\%20torgovle\%20mezhdu\%20stranami\%20EAES\%20i\%20V'etnamom.pdf. (Accessed: 12 th June 2018).

6. Eurasian Economic Commission. (2018c) Liberalizatsiya torgovogo rezhima mezhdu EAES $i$ V'etnamom pozvolila za posledniy god narastit' tovarooborot mezhdu storonami na 36\% [Liberalization of the trade regime between the EAEU and Vietnam over the past year has increased the trade turnover between the parties by 36\%]. [Online] Available from: http://www.eurasiancommission.org/ru/nae/news/Pages/19-06-2018-2.aspx. (Accessed: 27th September 2018).

7. Eurasian Economic Commission. (2018d) Podpisano Vremennoe soglashenie, vedushchee $k$ obrazovaniyu zony svobodnoy torgovli mezhdu EAES $i$ Iranom [The EAEU and Iran signed a temporary agreement on the formation of a free trade zone]. [Online] Available from: http://www.eurasiancommission.org/ru/nae/news/Pages/17-05-2018-1.aspx. (Accessed: 26th September 2018).

8. Eurasian Economic Commission. (2018e) Provodime peregovory po zaklyucheniyu soglasheniy o svobodnoy torgovle mezhdu EAES $i$ tret'imi stranami. Po sostoyaniyu na sentyabr' 2018 god [Ongoing negotiations to conclude free trade agreements between the EAEU and third countries. As of September 2018]. [Online] Available from: http://www.eurasiancommission.org/ru/act/trade/dotp/sogl_torg/Documents/Provodimye\%20peregovory\%20sst_sayt.pdf. (Accessed: 27th September 2018).

9. Eurasian Economic Commission. (2018f) EAES i Respublika Koreya podpisali Memorandum o sotrudnichestve [The EAEU and the Republic of Korea signed a Memorandum of Cooperation]. [Online] Available from: http://www.eurasiancommission.org/ru/nae/news/Pages/30-11-2015-5.aspx. (Accessed: 15th June 2018).

10. Eurasian Economic Commission. (2018g) Vneshnyaya torgovlya s tret'imi stranami [Foreign trade with third countries]. [Online] Available from: http://www.eurasiancommission.org/ru/act/integr_i_makroec/dep_stat/tradestat/tables/extra/Documents/2017/12+/E201712_2_4.pdf. (Accessed: 29th September 2018).

11. Eurasian Economic Commission. (2018h) Annotatsiya $k$ rezul'tatam nauchno-issledovatel'skoy raboty na temu "Opredelenie perspektivnykh partnerov gosudarstv-chlenov Tamozhennogo Soyuza po zaklyucheniyu soglasheniy o svobodnoy torgovle" [Annotation to the results of research work on the theme "Identification of promising partners of the Member States of the Customs Union for the conclusion of free trade agreements"]. [Online] Available from: http://www.eurasiancommission.org/ru/NIR/Lists/List/Attachments/35/18_12_2013_annot.pdf. (Accessed: 15th June 2018).

12. Kadochnikov, P.A., Rogatnykh, E.B., German, E.I., Aliev, T.M. et al. (2016) Otsenka tekushchego rossiysko-koreyskogo ekonomicheskogo sotrudnichestva i perspektivy razvitiya na sredne- $i$ dolgosrochnyy period [Assessment of the current Russian-Korean economic cooperation and development prospects for the medium and long-term period]. Moscow: VAVT. [Online] Available from: http://www.kiep.go.kr/sub/view.do?bbsId= search_report\&nttId=189412. (Accessed: 10th October 2018).

13. Nikishina, V. (2017) “Za otkrytie rynkov stran-partnerov my dolzhny zaplatit' snizheniem poshlin”. Ministr torgovli EEK Veronika Nikishina o planakh po rasshireniyu svobodnoy torgovli ["A decrease in fees is to be paid for the opening of the markets of partner countries", the EEC Trade Minister Veronika Nikishina on plans to expand free trade]. Kommersant. 10th February. [Online] Available from: https://www.kommersant.ru/doc/3214431. (Accessed: 15th October 2018).

14. Larionova, A. (2017) NPP "Poliplastik" prosit Mintorg ogranichit' svobodnuyu torgovlyu s Yuzhnoy Koreey [NPP "Polyplastic" asks the Ministry of Trade to restrict free trade with South Korea]. [Online] Available from: http://www.mrcplast.ru/news-news_open-327675.html. (Accessed: 29th September 2018).

15. The Administration of the President of the Russian Federation. (2018) Sovmestnoe zayavlenie Rossiyskoy Federatsii $i$ Respubliki Koreya. 22 iyunya 2018 goda [Joint Statement of the Russian Federation and the Republic of Korea. June 22, 2018]. [Online] Available from: http://kremlin.ru/supplement/5321. (Accessed: 29th September 2018). 